LETTER TO JMG

\title{
Tiling path resolution mapping of constitutional 1p36 deletions by array-CGH: contiguous gene deletion or "deletion with positional effect" syndrome?
}

\author{
R Redon, M Rio, S G Gregory, R A Cooper, H Fiegler, D Sanlaville, R Baneriee, C Scott, \\ P Carr, C Langford, V Cormier-Daire, A Munnich, N P Carter, L Colleaux
}

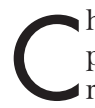
hromosomal anomalies account for a substantial proportion of syndromes associated with mental retardation. Some of these anomalies result in a specific phenotype which may direct the clinician towards the diagnosis. ${ }^{12}$ Deletion of the most distal band on the short arm of chromosome 1 (lp36) is the most common terminal deletion syndrome, affecting 1 out of 5000 newborns. It results in a clinically recognisable syndrome characterised by a specific facial gestalt including large anterior fontanel, deep-set eyes, flat nasal bridge, asymmetric ears, and pointed chin. ${ }^{3}$ Additional clinical features include learning disability, seizure, cardiomyopathy, and hearing impairment.

Detailed molecular characterisation of patients with 1p36 constitutional deletions showed variability in the parental origin, deletion size, and complexity of the chromosomal rearrangements, as well as in the clinical presentation of the syndrome. ${ }^{3}$ These observations led $\mathrm{Wu}$ et al to propose that "haploinsufficiency of contiguous, but functionally unrelated, genes in the deletion region are responsible for the phenotypic features". Therefore, they postulated that "refining the sizes of the deletions in affected individuals, in conjunction with phenotype/genotype correlation, will aid in identifying candidate genes within critical deletion intervals" ${ }^{5}$

Indeed, genotype/phenotype correlations allowed the assignment of certain clinical features to specific deletion intervals. In particular, the critical region associated with hearing loss was refined ${ }^{5}$ and some candidate genes associated with epilepsy phenotype ${ }^{6}$ and clefting abnormalities were identified. ${ }^{7}$

More recently, microarray based comparative genomic hybridisation (array-CGH) was applied to DNA from patients with 1 p36 constitutional deletions. ${ }^{8}$ Results showed the accuracy of array-CGH for detection of single DNA copy number changes and fine mapping of imbalance breakpoints.

In this study, we applied array-CGH to six patients showing clinical features characteristic of monosomy 1 p36 with a microarray composed of 2221 overlapping clones covering $99.5 \%$ of the euchromatic portion of chromosome 1 to further delineate genotype/phenotype correlations in monosomy 1p36. Our data not only contradict previous results but, through the observation that two patients had non-overlapping lp36 deletions, suggest that the monosomy lp36 syndrome may be due to a positional effect of the 1 p36 rearrangement rather than haploinsufficiency of contiguous genes in the deleted region.

\section{METHODS}

\section{Patients}

Six unrelated patients, one male and five females, were included in this study. Patients were referred to the Genetic Department of the Necker-Enfants Malades hospital for

\section{Key points}

- The constitutional $1 \mathrm{p} 36$ deletion is the most common terminal deletion syndrome, affecting 1 out of 5000 newborns. It results in the association of a characteristic facial dysmorphism (including: large anterior fontanel, deep-set eyes, flat nasal bridge, asymmetric ears, and pointed chin), congenital anomalies, and learning disability/mental retardation.

- We have applied microarray based comparative genomic hybridisation (array-CGH), using an overlapping clone microarray covering $99.5 \%$ of the euchromatic portion of chromosome 1, for six patients showing clinical features characteristic of monosomy 1 36.

- Deletions were confirmed in all cases. Two patients were of particular interest: the first one had a deletion restricted to the most terminal $2.5 \mathrm{Mb}$ of $1 \mathrm{p} 36.33$; the second one had a deletion of $6.9 \mathrm{Mb}$ in length, starting $3 \mathrm{Mb}$ from the terminal region.

- Considering that the two patients exhibit very similar features (facial characteristics and mental retardation), the occurrence of non-overlapping $1 \mathrm{p} 36$ deletions strongly suggests that monosomy $1 \mathrm{p} 36$ may be a deletion with positional effect rather than a contiguous gene deletion syndrome.

- Our results indicate that concomitant FISH screening of several 1 p36 loci or the use of high resolution array$\mathrm{CGH}$ will be required for full diagnosis of this syndrome.

investigation of their developmental delay or learning disability. Informed consent was obtained from all patients and their parents. The clinical characteristics of the six patients are presented in table 1. In five patients, monosomy lp36 was primarily suspected on clinical evaluation. For patients $\mathrm{A}$ and $\mathrm{B}$, the diagnosis was confirmed by chromosomal GTG (G-bands by trypsin using Giemsa) analysis at ISCN 550-850. For patients C, E, and F, RHG (R-bands by heat using Giemsa) and GTG showed a normal karyotype, but their facial features prompted us to test for 1 p36 monosomy by FISH and genotyping. Finally patient D, who was

Abbreviations: array- $\mathrm{CGH}$, microarray based comparative genomic hybridisation; FISH, fluorescent in situ hybridisation; GTG, G-bands by trypsin using Giemsa; RHG, R-bands by heat using Giemsa; TAR, telomere associated repeat 
Table 1 Clinical manifestations in children with $1 \mathrm{p} 36$ deletion

\begin{tabular}{|c|c|c|c|c|c|c|}
\hline & A & B & C & D & $\mathbf{E}$ & $\mathbf{F}$ \\
\hline Sex & $\mathrm{F}$ & $\mathrm{F}$ & $\mathrm{F}$ & $M$ & $\mathrm{~F}$ & $\mathrm{~F}$ \\
\hline Paternal age at birth & 30 & 27 & 31 & 28 & 33 & 29 \\
\hline $\begin{array}{l}\text { Maternal age at birth } \\
\text { Birth }\end{array}$ & \multicolumn{6}{|c|}{ Birth } \\
\hline Gestation (AS) & 39 & 39 & 34 & 41 & 39 & 40.5 \\
\hline Weight & $<5$ th $p$ & $<5$ th $p$ & 50 & $10-50$ th $p$ & $<5$ th $p$ & 50th $p$ \\
\hline Body length & $<5$ th $p$ & 5th $p$ & 90th $\mathrm{p}$ & 50th $p$ & 50th $p$ & $50-90$ th $p$ \\
\hline OFC & 10th $p$ & 50th $p$ & 50th $\mathrm{p}$ & 50th $p$ & 5-10th $p$ & 50th $\mathrm{p}$ \\
\hline Feedings difficulties & + & + & - & - & & + \\
\hline Age at diagnosis & 16 months & $\begin{array}{l}2 \text { years } \\
8 \text { months }\end{array}$ & $\begin{array}{l}6 \text { years } \\
10 \text { months }\end{array}$ & 16 years & 19 years & 5 years \\
\hline \multicolumn{7}{|l|}{ Post natal growth } \\
\hline Weight & $-3 S D$ & $-2.5 \mathrm{SD}$ & $+1 \mathrm{SD}$ & $-1 S D$ & $-1 S D$ & $+1 \mathrm{SD}$ \\
\hline Height & $\begin{array}{l}-3 S D \\
-2 S D\end{array}$ & $-0.5 \mathrm{SD}$ & $\begin{array}{l}-2 S D \\
-1 S D\end{array}$ & $\begin{array}{l}-2 S D \\
-1 S D\end{array}$ & $-2.5 \mathrm{SD}$ & $0 \mathrm{SD}$ \\
\hline Truncal distribution of & - & - & + & - & + & + \\
\hline \multicolumn{7}{|l|}{ Neurological findings } \\
\hline Mental retardation & + & + & + & + & + & + \\
\hline $\begin{array}{l}\text { Motor delay and } \\
\text { hypotonia }\end{array}$ & + & + & + & + & + & + \\
\hline Walk & - (at 42 months) & - (at 36 months) & 4 years & 6 years & 24 months & 3.5 years \\
\hline Speech & - & - & - & - & + & - \\
\hline Behavioural anomalies & - & - & Hyperphagia & $\begin{array}{l}\text { Autoaggressive } \\
\text { behaviour, } \\
\text { autistic features }\end{array}$ & $\begin{array}{l}\text { Autoaggressive } \\
\text { behaviour }\end{array}$ & $\begin{array}{l}\text { Sleep disturbances, } \\
\text { autoaggressive } \\
\text { behaviour }\end{array}$ \\
\hline $\begin{array}{l}\text { Unsteady gait with a } \\
\text { wide base }\end{array}$ & $?$ & $?$ & + & + & + & - \\
\hline Epilepsy & + & + & + & - & + & - \\
\hline Cardiovascular findings & $\begin{array}{l}\text { Atrial and ventricular } \\
\text { septal defect }\end{array}$ & - & Ebstein anomaly & - & - & Ebstein anomaly \\
\hline \multicolumn{7}{|l|}{$\begin{array}{l}\text { Ophthalmological } \\
\text { and auditory findings }\end{array}$} \\
\hline Nystagmus & + & + & + & + & - & - \\
\hline Strabismus & - & + & + & + & - & - \\
\hline Deafness & - & - & - & - & - & + \\
\hline \multicolumn{7}{|l|}{ Physical characteristics } \\
\hline Facies & & & & & & \\
\hline Brachycephaly & + & + & + & - & - & + \\
\hline Plagiocephaly & + & - & - & - & - & - \\
\hline Large anterior fontanel & + & $?$ & $?$ & $?$ & $?$ & ? \\
\hline Large forehead & + & + & + & - & + & + \\
\hline Flat mid-face & + & + & + & + & + & + \\
\hline \multicolumn{7}{|l|}{ Eyes } \\
\hline Deep-set eyes & + & + & + & + & + & + \\
\hline Short palpebral fissures & + & + & + & + & + & + \\
\hline Epicanthic folds & + & + & + & - & + & - \\
\hline Straight eyebrows & + & + & + & + & + & + \\
\hline $\begin{array}{l}\text { Prominent supra } \\
\text { orbital ridges }\end{array}$ & & + & + & + & + & \\
\hline \multicolumn{7}{|l|}{ Nose } \\
\hline $\begin{array}{l}\text { Flat or depressed } \\
\text { nasal bridge }\end{array}$ & + & + & + (in infancy) & - & + (in infancy) & - \\
\hline High nasal bridge & - & - & + & + & + & + \\
\hline \multicolumn{7}{|l|}{ Ears } \\
\hline Small ears & + & + & - & + & + & - \\
\hline Low-set ears & + & - & - & + & - & - \\
\hline Thickened ear helices & - & + & - & + & + & + \\
\hline Dysplastic helices & + & + & - & + & - & - \\
\hline \multicolumn{7}{|l|}{ Mouth and chin } \\
\hline $\begin{array}{l}\text { Mouth with } \\
\text { downturned corners }\end{array}$ & + & + & + & + & + & + \\
\hline Small mouth & + & + & + & + & + & + \\
\hline $\begin{array}{l}\text { Pointed or prominent } \\
\text { chin }\end{array}$ & + & + & + & + & + & + \\
\hline \multicolumn{7}{|l|}{ Hands } \\
\hline Small hands & + & + & + & - & + & + \\
\hline Short fifth finger & - & + & + & - & + & - \\
\hline Fifth finger clinodactyly & + & + & + & + & - & - \\
\hline Orofacial clefting & - & - & - & - & - & - \\
\hline
\end{tabular}


Table 2 Genotyping and FISH results with markers and probes from the $1 \mathrm{p} 36$ region

\begin{tabular}{|c|c|c|c|c|c|c|c|}
\hline Locus & $\begin{array}{l}\text { Distance from } 1 p \\
\text { telomere }(M b)\end{array}$ & $\mathbf{E}$ & $\mathbf{F}$ & B & D & C & A \\
\hline $\mathrm{CA} / 140 \mathrm{~A} 9$ & 1.6 & Pat Del & $\mathrm{NI}$ & Mat Del & Pat Del & Pat Del & Pat Del \\
\hline D1S243 & 2 & $\mathrm{NI}$ & $\mathrm{N}$ & Mat Del & Pat Del & $\mathrm{NI}$ & Pat Del \\
\hline SKI & 2.1 & Pat Del & $\mathrm{N}$ & Del & Del & Del & Del \\
\hline CA/740P5 & 2.4 & $\mathrm{~N}$ & $N$ & Mat Del & $\mathrm{NI}$ & Pat Del & Pat Del \\
\hline D1S468 & 3.3 & $\mathrm{~N}$ & Mat Del & Mat Del & Pat Del & Pat Del & $\mathrm{NI}$ \\
\hline D1S2845 & 4.1 & ND & $\mathrm{NI}$ & Mat Del & $\mathrm{NI}$ & Pat Del & Pat Del \\
\hline KCNAB2 & 5.8 & ND & Del & ND & ND & ND & ND \\
\hline D1S214 & 6.6 & ND & Mat Del & $\mathrm{NI}$ & $\mathrm{NI}$ & $N$ & $\mathrm{NI}$ \\
\hline D1S450 & 9.2 & ND & Mat Del & $N$ & $\mathrm{NI}$ & $\mathrm{NI}$ & Pat Del \\
\hline D1S2667 & 11.2 & ND & $\mathrm{N}$ & $N$ & $N$ & $N$ & $\mathrm{~N}$ \\
\hline
\end{tabular}

evaluated 5 years earlier (that is prior to the 1 p36 monosomy phenotype characterisation), had a normal karyotype. Based on the association of severe learning disability and facial dysmorphism, this patient was assayed for cryptic telomeric rearrangements using genotyping, ${ }^{9}$ leading to the identification of a lp36 deletion.

\section{Chromosome and FISH analyses}

Metaphase spreads were prepared from phytohaemaglutinin stimulated peripheral blood lymphocyte cultures using standard procedures of hypotonic treatment and methanol/ acetic acid fixation (3:1). RHG and GTG banding analyses were performed according to standard protocols. Fluorescent in situ hybridisation (FISH) for clone verification was conducted following conventional methods using metaphase chromosomes prepared from a karyotypically normal male lymphoblastoid cell line. Degenerate oligonucleotide primer (DOP) amplified clone DNA (used in array production) was labelled with biotin-16-dUTP (Roche, Mannheim, Germany) or digoxigenin-11-dUTP (Roche) by nick translation. Biotin labelled probes were detected using Avidin TexasRed (Molecular Probes, Eugene, OR, USA), while digoxigenin labelled probes were detected with a combination of mouse antidigoxigenin (Vector Laboratories, Peterborough, UK) and goat anti-mouse FITC (Sigma-Aldrich, Dorset, UK) antibodies.

\section{Molecular analysis}

Blood samples from probands and their parents were obtained and genomic DNA was isolated from EDTA anticoagulated blood by a salting out procedure. Eight polymorphic microsatellite markers were used (table 2). Fluorescent genotyping was performed as previously described. ${ }^{9}$

\section{Array-CGH}

Large-insert clones used for the construction of the chromosome 1 genomic microarray were chosen from chromosome 1 sequence-ready bacterial clone contigs, based upon their contribution towards the minimum tiling path of the chromosome. Whenever possible, clones were re-picked from glycerol stocks that had been streaked to single colony and used for the generation of genomic shotgun sequence. Any clone that was not available via this route was streaked to single colony from re-arrayed chromosome 1 plate sets derived from genomic BAC and PAC libraries as part of the chromosome 1 physical mapping project. Following extraction (as previously described ${ }^{10}$ ), every cloned DNA was re-fingerprinted ${ }^{11}$ and compared to the original restriction fingerprint within the physical map using FPC. ${ }^{12}$ Only clones that generated restriction fingerprint patterns identical to the original data were included. DOP-PCR and amino linked PCR products were then generated, arrayed onto amine binding slides (CodeLink Activated Slides, Amersham Biosciences, Buckinghamshire, UK) and hybridised as previously described. ${ }^{13} 14$

\section{Image acquisition and analysis}

Arrays were scanned using an Agilent scanner (Agilent Technologies, Palo Alto, CA, USA). Fluorescent intensities were extracted using GenePix Pro 3.0 software (Axon Instruments, Union City, CA, USA). Spots were defined by use of the automatic grid feature of the software and manually adjusted where necessary. Spots with fluorescence intensities lower than twice the local background value were excluded from analysis. Fluorescence intensities of all spots were then corrected by subtraction of the local background value. Mean values for each duplicate spot were obtained. Clones were excluded whenever the individual values obtained for the duplicates differed from each other by more than $10 \%$. Clones were mapped using the NCBI Build 34 of the human genome sequence, according to whole sequence or end sequencing data. Data were normalised by dividing the mean ratio of each clone duplicate by the mean ratio of all clones located on the long arm of chromosome 1. The standard deviation of hybridisation ratios for all clones located on lq was then calculated in each experiment. We considered one locus deleted or duplicated where the hybridisation ratio of corresponding clones exceeded the value of the lq mean plus or minus four times the $\mathrm{lq}$ standard deviation for one particular hybridisation experiment. Clones showing physical mapping inaccuracies or hybridisation to multiple loci by FISH on normal metaphase spreads were removed from the analysis, as well as clones giving invariable ratios when hybridised using normal genomic DNA against the same DNA enriched by the addition of flow sorted chromosome I DNA (see supplementary data, fig Wl, available from http://jmg.bmjjournals.com/ supplemental).

\section{RESULTS}

Six patients with characteristic lpter monosomy facial gestalt were analysed. FISH and genotyping results are summarised in table 2. All cases were de novo since parental chromosomes were normal. Two cases showed a maternally derived deletion, while in the remaining four cases the deletion was paternally derived. To further delineate deleted segments in patients with lp36 monosomy syndrome, we used a microarray constructed with overlapping BAC/PAC clones derived from the human chromosome 1 sequencing project, covering $99.5 \%$ of the euchromatic portion of the chromosome.

Array-CGH results confirmed the six deletions, with sizes ranging from 2 to $10 \mathrm{Mb}$ (fig $\mathrm{lA}, \mathrm{B}$ and supplemental data, fig 


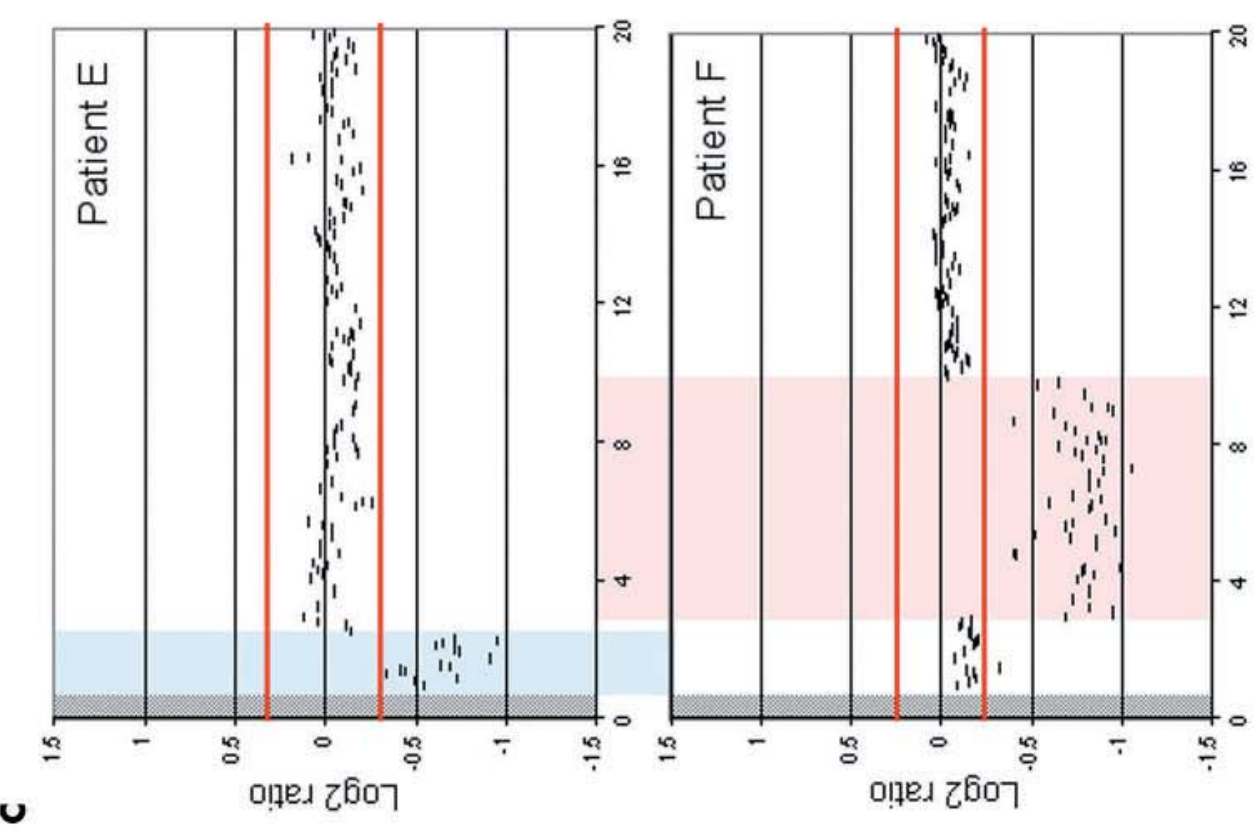

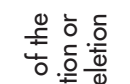

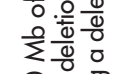

으웡 온

$2 \quad \overline{\bar{t}} \frac{0}{\mathrm{c}}$

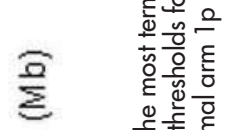

일

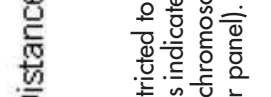

步

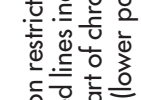

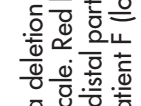

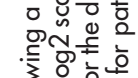

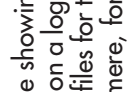

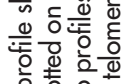

읗응은은 응

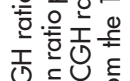

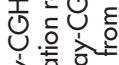

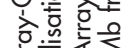
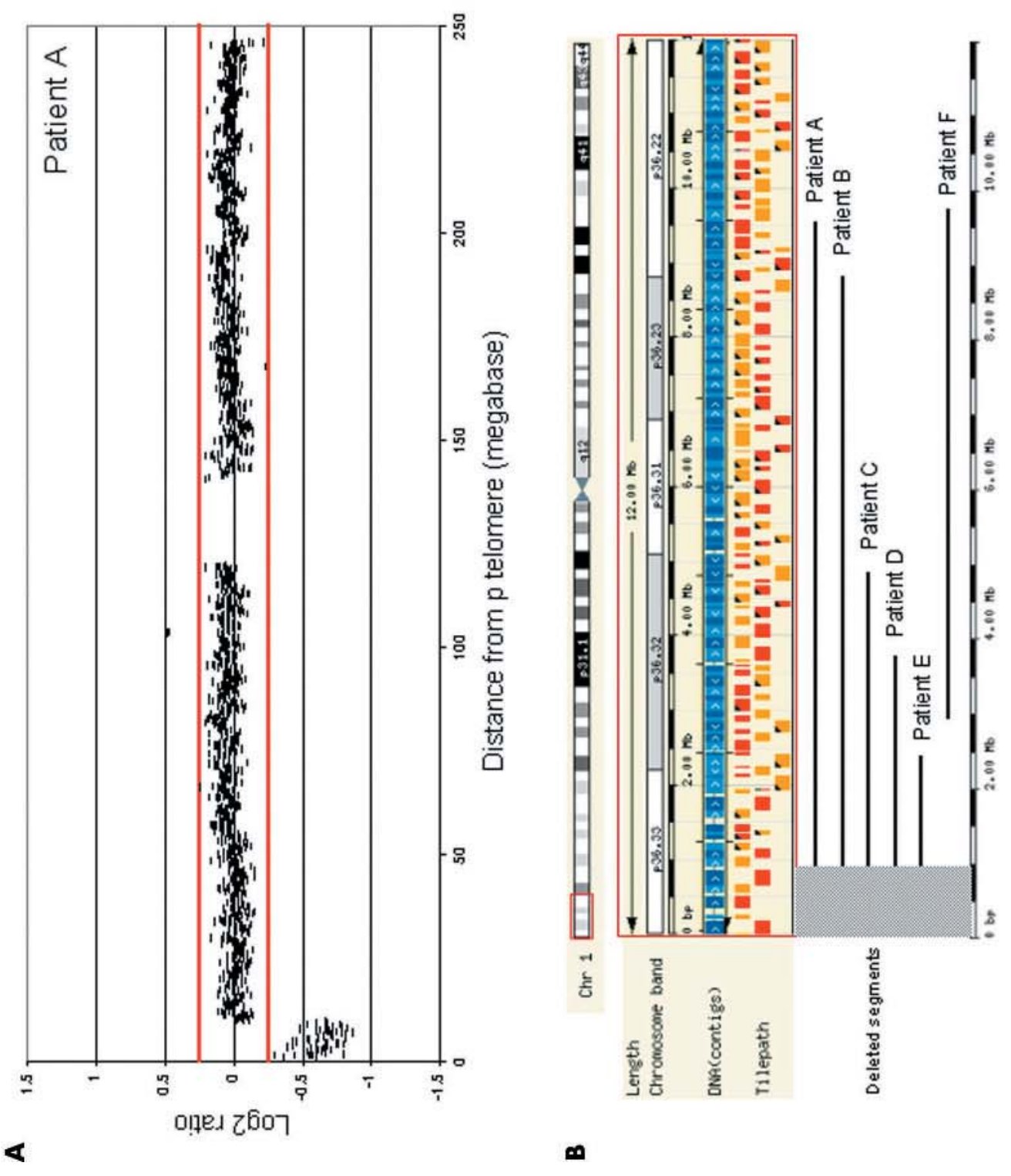

흐슴ำ

हैं

行

을 흐음 흥

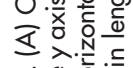

हैं

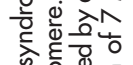

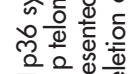

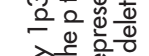

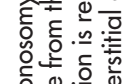

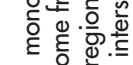

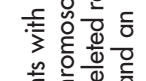

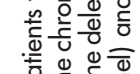

.

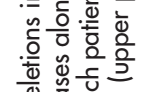

क

응ㅎㅀㅎㅎㄴ흫

है

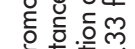

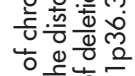

ơ

응 흘루

ह. $\frac{n}{8}$ हो ?

윽 $\times$ 음ำ

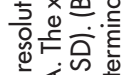

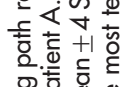

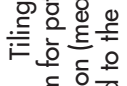

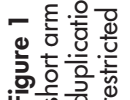

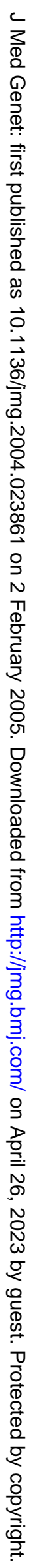




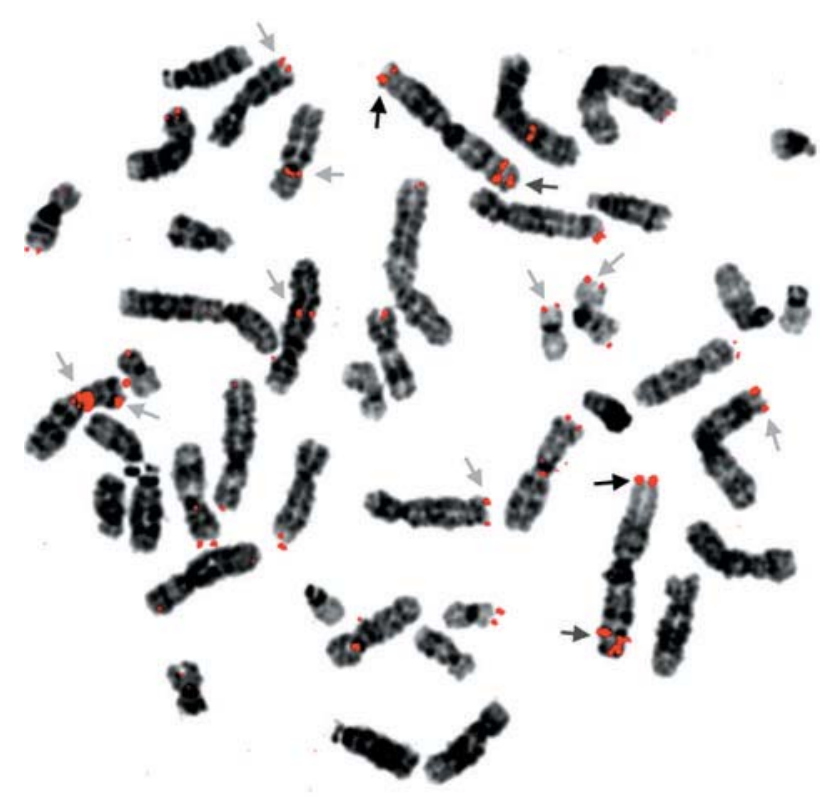

Figure 2 Clone RP11-206L10 gives multiple signals on human normal metaphase chromosomes by fluorescence in situ hybridisation. RP1 1206L10, labelled in red, is mapped on chromosome 1 at position 0.67$0.84 \mathrm{Mb}$ (1p36.33) using the human genome sequence NCBI Build 34. By FISH, in addition to one signal at 1p36.3 (black arrows), this clone gives signals at $1 \mathrm{q} 41$ and $1 \mathrm{q} 42.3-\mathrm{q} 43$ (dark grey arrows) and at multiple other chromosomal loci, mostly located in subtelomeric and pericentromeric regions (examples indicated by light grey arrows).

W2, available at http://jmg.bmjjournals.com/supplemental). However, we found that the four more distal clones-RP1134P13, RP4-669L17, RP5-857K21, and RP11-206L10invariably gave normal hybridisation ratios. These clones map to the telomere associated repeat (TAR) region of $1 \mathrm{p} 36$ and may therefore also hybridise with other repetitive regions. To confirm this hypothesis, we hybridised clone RP11-206L10 to normal metaphase chromosomes (fig 2). This clone showed multiple signals not only in 1 p36.3 but also in other loci mainly distributed near chromosome centromeres and telomeres. We concluded that, because of this strong cross-hybridisation with multiple loci along the genome, the four most distal clones were not usable for deletion mapping. Thus, the most distal clone allowing detection of $1 p$ loss in this study is RP11-465B22, mapped at positions $0.90-1.03 \mathrm{Mb}$ on NCBI Build 34 .

\begin{tabular}{|c|c|c|c|}
\hline Patient & Distal border* & Proximal border* & $\begin{array}{l}\text { Deletion size } \\
\text { (Mb) }\end{array}$ \\
\hline A & - & $\begin{array}{l}\text { RP1 1-496H15 } \\
(9.77-9.86 \mathrm{Mb})\end{array}$ & 9.8 \\
\hline B & - & $\begin{array}{l}\text { RP11-510D11 } \\
\text { (8.92-9.05 Mb) }\end{array}$ & 8.9 \\
\hline c & - & $\begin{array}{l}\text { RP5-135B10 } \\
(4.69-4.87 \mathrm{Mb})\end{array}$ & 4.7 \\
\hline D & - & $\begin{array}{l}\text { RP1 1-374C13 } \\
(3.85-3.99 \mathrm{Mb})\end{array}$ & 3.9 \\
\hline$E$ & - & $\begin{array}{l}\text { RP4-740P5 } \\
(2.48-2.59 \mathrm{Mb})\end{array}$ & 2.5 \\
\hline $\mathrm{F}$ & $\begin{array}{l}\text { RP1 1-193J6 } \\
(2.87-2.91 \mathrm{Mb})\end{array}$ & $\begin{array}{l}\text { RP1 1-420G9 } \\
(9.95-10.13 \mathrm{Mb})\end{array}$ & 7.0 \\
\hline
\end{tabular}

*Adjacent non-deleted clone (NCBI Build 34 coordinates on chromosome 1).
Array-CGH results allowed the fine mapping of the breakpoints (fig $\mathrm{IB}$ and table 3). Two patients were of particular interest (fig 1C). The first one, patient E, displayed a de novo deletion restricted to the most terminal $2.5 \mathrm{Mb}$ of lp36.33 since the proximal breakpoint is located within BAC RP4-755G5. The second patient (patient F) showed a de novo interstitial deletion of about $6.9 \mathrm{Mb}$ in length with a telomeric breakpoint located within clone RPI1-22L13, that is $3 \mathrm{Mb}$ from the telomere. Array-CGH experiments, performed using a microarray covering the whole genome with a distribution of one clone per megabase (including every subtelomeric region ${ }^{13}$ ), failed to detect any additional chromosomal imbalance, thus confirming that both patients $\mathrm{E}$ and $\mathrm{F}$ display pure constitutional lp36 deletions (data not shown). The characteristic lp36 deletion gestalt can therefore be the consequence of distinct and non-overlapping lp36 deletions.

\section{DISCUSSION}

The detailed molecular analysis of six patients with monosomy lp36 syndrome allowed us to confirm that array-CGH enables precise and accurate mapping of deletion breakpoints and subsequent genotype/phenotype comparison in one single experiment. ${ }^{8}$

Due to the cross-hybridisation of the four more distal $1 \mathrm{p} 36$ clones to many other chromosomal regions, it is difficult to tell whether these rearrangements correspond to terminal or interstitial deletions. Moreover, there are some gaps still remaining in the NCBI Build 34 of the human genome sequence, which was used for clone positioning in this study. Along the most terminal $12 \mathrm{Mb}$ of the chromosome 1 short arm, 11 gaps are still present, ranging from 50 to $100 \mathrm{~kb}$ in length. Sequencing and array-CGH difficulties can be mainly explained by the presence of many repetitive sequences, particularly in the TAR region, that could also be involved in generating and/or stabilising some terminal deletions. ${ }^{15}$ Additional studies, such as arraying PCR amplified unique sequence fragments rather than whole clones, will be required to better characterise rearrangements occurring near repetitive sequences.

Among the six patients analysed by array-CGH, two were of particular interest. The first one, patient $\mathrm{E}$, had a pure de novo deletion restricted to the most terminal $2.5 \mathrm{Mb}$ of 1p36.33. The second one, patient $\mathrm{F}$, showed a pure de novo interstitial $1 \mathrm{p} 36$ deletion of $7 \mathrm{Mb}$ in length excluding the most distal $2.9 \mathrm{Mb}$ segment.

Sixty one 1 p36 constitutional deletions have been reported recently, including pure terminal deletions, interstitial deletions, derivative chromosomes, and more complex rearrangements. ${ }^{16}$ Detailed molecular analyses of these deletions and phenotype/genotype correlations have narrowed the critical intervals for some features of the syndrome and allowed the identification of possible causative genes. ${ }^{16}$ Genes contributing to the craniofacial features of the syndrome were mapped distal to marker D1S2870, in a region encompassing about $6 \mathrm{Mb} .{ }^{5}$ The critical region corresponding to the genes involved in learning disability was mapped distal to D1S243 and proximal to D1S248. ${ }^{5}$ Experiments suggesting that the SKI proto-oncogene, located at distal $1 \mathrm{p} 36.3$, is involved in neural tube development and muscle differentiation and the observation that $\mathrm{Ski}^{-/-}$mice display a phenotype that resembles some of the features observed in individuals with lp36 deletion syndrome, led to the hypothesis that SKI gene haploinsufficiency may contribute to some of the phenotypes common in 1 p36 deletion syndrome. ${ }^{7}$ In addition, deletion of the potassium channel beta-subunit gene, KCNAB2, was considered to be a significant risk factor for epilepsy. ${ }^{6}$ Finally, the minimal critical deletion interval for hearing loss may reside distal to the BAC clone RP11-907A6. ${ }^{16}$ 
Interestingly, the clinical and molecular characterisation of patients $\mathrm{E}$ and $\mathrm{F}$ is not consistent with these results. First, while patient $\mathrm{E}$ has a small $2.5 \mathrm{Mb}$ subtelomeric deletion, which encompasses the BAC clone RPl1-436F16 containing marker D1Z2, she has a mild mental retardation with speech abilities. Second, although patient $F$ has deafness, the causative deletion does not include the corresponding minimal critical interval. Third, patient $\mathrm{E}$ suffers from seizures with a lp36 deletion excluding KCNAB2. Finally, patients $\mathrm{E}$ and $\mathrm{F}$, while displaying very similar features (facial characteristics and mental retardation), exhibit distinct and non-overlapping 1 p36 deletions. This result suggests that some clinical traits of the 1 p36 monosomy could be due to the altered expression of a number of genes adjacent to the deleted segment, but not deleted themselves. This phenomenon, called position effect, is poorly understood. Several hypotheses have been formed, following the description of different chromosomal rearrangements occurring next to disease causing genes in human developmental disorders ${ }^{17}$ : (1) the rearrangement could give rise to classical position effect variegation (a variable, but heritably stable inhibition of gene expression due to the juxtaposition of a euchromatic gene with a region of heterochromatin); (2) the chromosomal rearrangement could separate the transcription unit from an essential regulatory element; (3) conversely, the rearrangement could place the gene under the control of inappropriate regulatory sequences; and (4) by bringing two genes closer together, the rearrangement could result in competition for the regulatory element between the two genes, thus altering their expression levels.

Although the precise mechanism of position effect remains to be elucidated, our results clearly demonstrate that the lp36 phenotype can be the consequence of different, nonoverlapping deletions, and lead us to propose that: (1) monosomy 1 p36 is not a simple contiguous gene deletion syndrome; and (2) deletions of variable size and mapping can account for the characteristic phenotype by position effect on one or more genes along the 1 p36 region. We therefore suggest giving consideration to the use of at least two different FISH probes and/or the use of high resolution array$\mathrm{CGH}$ for the systematic testing of patients with clinical features suggestive of monosomy $1 \mathrm{p} 36$.

\section{ACKNOWLEDGEMENTS}

We thank the chromosome 1 mapping and sequencing groups at the Sanger Institute, as well as Oliver Dovey, Bee Ling Ng, and Susan Bryant for expert technical assistance. We are grateful to Stanislas Lyonnet, Jeanne Amiel, and Martine le Merrer for clinical support. We also thank Odile Raoul, Marguerite Prieur, Marie-Christine de Blois, and Michel Vekemans for cytogenetic analyses.

\section{ELECTRONIC-DATABASE INFORMATION}

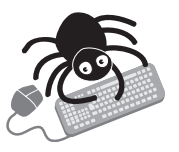

Supplementary information is available from $\mathrm{http}: / /$ jimg.bmijournals.com/supplemental.

\section{Authors' affiliations}

R Redon, R A Cooper, H Fiegler, R Baneriee, C Scott, P Carr,

C Langford, N P Carter, The Wellcome Trust Sanger Institute, Wellcome Trust Genome Campus, Hinxton, Cambridge, UK

M Rio, D Sanlaville, V Cormier-Daire, A Munnich, L Colleaux, INSERM U393 and Département de Génétique, Hôpital Necker-Enfants Malades, rue de Sèvres, Paris, France
S G Gregory, Center for Human Genetics, Duke University Medical Center, Durham, NC, USA

This work was funded by the Wellcome Trust and by INSERM. Richard Redon was supported by a Sanger Institute Postdoctoral Fellowship.

Competing interests: none declared

Correspondence to: Dr R Redon, The Wellcome Trust Sanger Institute, Wellcome Trust Genome Campus, Hinxton, Cambridge CB10 1SA, UK; rr2@sanger.ac.uk

Received 11 June 2004

Revised version received 13 July 2004

\section{REFERENCES}

1 De Vries BB, Knight SJ, Homfray T, Smithson SF, Flint J, Winter RM Submicroscopic subtelomeric lqter deletions: a recognisable phenotype? J Med Genet 2001;38:175-8.

2 Cormier-Daire V, Molinari F, Rio M, Raoul O, de Blois MC, Romana S, Vekemans M, Munnich A, Colleaux L. Cryptic terminal deletion of chromosome 9q34: a novel cause of syndromic obesity in childhood? J Med Genet 2003;40:300-3.

3 Shapira SK, McCaskill C, Northrup H, Spikes AS, Elder FF, Sutton VR, Korenberg JR, Greenberg F, Shaffer LG. Chromosome 1p36 deletions: the clinical phenotype and molecular characterization of a common newly delineated syndrome. Am J Hum Genet 1997;61:642-50.

4 Slavotinek A, Shaffer LG, Shapira SK. Monosomy 1p36. J Med Genet 1999:36:657-63.

5 Wu YQ, Heilstedt HA, Bedell JA, May KM, Starkey DE, McPherson JD, Shapira SK, Shaffer LG. Molecular refinement of the 1 p36 deletion syndrome reveals size diversity and a preponderance of maternally derived deletions. Hum Mol Genet 1999:8:313-21.

6 Heilstedt HA, Burgess DL, Anderson AE, Chedrawi A, Tharp B, Lee O, Kashork CD, Starkey DE, WU YQ, Noebels JL, Shaffer LG, Shapira SK. Loss of the potassium channel beta-subunit gene, KCNAB2, is associated with epilepsy in patients with 1 p36 deletion syndrome. Epilepsia 2001:42:1103-11.

7 Colmenares C, Heilstedt HA, Shaffer LG, Schwartz S, Berk M, Murray JC, Stavnezer E. Loss of the SKI proto-oncogene in individuals affected with 1 p36 deletion syndrome is predicted by strain-dependent defects in Ski-/- mice. Nat Genet 2002;30:106-9.

8 Yu W, Ballif BC, Kashork CD, Heilstedt HA, Howard LA, Cai WW, White LD, Liu W, Beaudet AL, Bejiani BA, Shaw CA, Shaffer LG. Development of a comparative genomic hybridization microarray and demonstration of its utility with 25 well-characterized 1 p36 deletions. Hum Mol Genet 2003; 12:2145-52

9 Rio M, Molinari F, Heuertz S, Ozilou C, Gosset P, Raoul O, Cormier-Daire V, Amiel J, Lyonnet S, Le Merrer M, Turleau C, de Blois MC, Prieur M, Romana S, Vekemans M, Munnich A, Colleaux L. Automated fluorescent genotyping detects $10 \%$ of cryptic subtelomeric rearrangements in idiopathic syndromic mental retardation. J Med Genet 2002;39:266-70.

10 Marra MA, Kucaba TA, Dietrich NL, Green ED, Brownstein B, Wilson RK, McDonald KM, Hillier LW, McPherson JD, Waterston RH. High throughput fingerprint analysis of large-insert clones. Genome Res 1997;7:1072-84

11 Gregory SG, Howell GR, Bentley DR. Genome mapping by fluorescent fingerprinting. Genome Res 1997;7:1162-8.

12 Soderlund C, Longden I, Mott R. FPC: a system for building contigs from restriction fingerprinted clones. Comput Appl Biosci 1997; 13:523-35.

13 Fiegler H, Carr P, Douglas EJ, Burford DC, Hunt S, Scott CE, Smith J, Vetrie D, Gorman P, Tomlinson IP, Carter NP. DNA microarrays for comparative genomic hybridization based on DOP-PCR amplification of BAC and PAC clones. Genes Chromosomes Cancer 2003;36:361-74.

14 Shaw-Smith C, Redon R, Rickman L, Rio M, Willatt L, Fiegler H, Firth H, Sanlaville D, Winter R, Colleaux L, Bobrow M, Carter NP. Microarray based comparative genomic hybridisation (array-CGH) detects submicroscopic chromosomal deletions and duplications in patients with learning disability/mental retardation and dysmorphic features. J Med Gene 2004:41:241-8.

15 Ballif BC, Gajecka M, Shaffer LG. Monosomy 1p36 breakpoints indicate repetitive DNA sequence elements may be involved in generating and/or stabilizing some terminal deletions. Chromosome Res 2004; 12:133-41.

16 Heilstedt HA, Ballif BC, Howard LA, Lewis RA, Stal S, Kashork CD, Bacino CA, Shapira SK, Shaffer LG. Physical map of 1p36, placement of breakpoints in monosomy 1p36, and clinical characterization of the syndrome. Am J Hum Genet 2003;72:1200-12.

17 Kleinjan DJ, van Heyningen V. Position effect in human genetic disease. Hum Mol Genet 1998;7:1611-8. 